\title{
Macroeconomic Effects of Fiscal Policy Shock in Nigeria: A SVAR Approach
}

\author{
Usenobong Friday Akpan, Johnson Akpan Atan \\ Department of Economics, Faculty of Social Sciences, University of Uyo, Uyo, Akwa Ibom State, Nigeria
}

Email address:

uakpan@yahoo.co.uk (U. F. Akpan), johnsonatan@yahoo.com (J. A. Atan)

\section{To cite this article:}

Usenobong Friday Akpan, Johnson Akpan Atan. Macroeconomic Effects of Fiscal Policy Shock in Nigeria: A SVAR Approach. International Journal of Business and Economics Research. Vol. 4, No. 3, 2015, pp. 109-120. doi: 10.11648/j.ijber.20150403.14

\begin{abstract}
This paper investigates the macroeconomic effects of fiscal policy shock in Nigeria using a Structural Vector Autoregressive (SVAR) framework on quarterly data for the period 1980:1-2010:4. From the empirical findings, the responses of real output and inflation may be asymmetrical depending on the component of government spending used as a fiscal stimulus to stabilized the economy. Basically, a positive shock to government capital spending on social and community services was found to have a persistent positive and significant impact on private consumption and real output but at the cost of higher inflation in the short term. A positive shock to oil revenue yield a significant positive impact on real output through its impact on public spending. In line with theory, the response of real output to innovations in business taxes is persistently negative, though insignificant. Private investment decisions in Nigeria does not seem to depend on the taxes paid to government, but on the cost of capital (interest rate) and perhaps on other crucial variables like market demand and profit expectations. The entire analysis clearly supports the argument that for the Nigerian experience, government is still relevant in stimulating real output through expenditure expansion on productive activities.
\end{abstract}

Keywords: Fiscal Policy, Real Output, SVAR, Government Spending

\section{Introduction}

The role of fiscal policy in stimulating real output growth has long generated extensive theoretical and empirical debate in the literature. Opinions vary considerably about the effect of fiscal policy and other selective government interventions in stimulating economic growth. Generally, exponents of these diverse opinions fall into two broad schools. While the first emphasizes that government fiscal activities can stimulate economic activities and thus output, others argued that government fiscal operations are inherently bureaucratic and inefficient and therefore stifles growth. Unfortunately, a common picture is yet to emerge from the vast empirical literature. This lack of consensus clearly opens door for more empirical quest. The aim of this paper is not to resolve the raging debate but to add to the fiscal policy-output literature by examining the case of a developing country like Nigeria. Specifically, the paper aims at deepening on the knowledge of the effects of exogenous fiscal policy shocks on a set of key macroeconomic variables in Nigeria within a VAR framework.

Generally, despite the extensive empirical literature on the impact of monetary policy shocks on macroeconomic activities, the influence of fiscal policy shock on the economy and therefore its importance for macroeconomic stabilization seem to have received limited empirical attention. To the best of our knowledge, the paucity of empirical studies on fiscal policy shocks is very striking in the case of Nigeria. However, the recent global financial crisis and the corresponding global recourse to fiscal stimulus for economic recovery have re-kindled the interest of academia, central bankers and policy makers on the role of fiscal policy. More so, the renewed interest on the issue could be observed in the European Monetary Union (EMU), where fiscal policy appears to remain the only policy instrument (on the demand side) in the hands of member states of the EMU to offset any adverse macroeconomic idiosyncratic shocks.

Against this background, this paper provides empirical evidence on the macroeconomic effects of fiscal policy shocks in Nigeria. Our benchmark specification of the VAR include quarterly data on total government expenditure, private investment, real output, inflation, and real interest rates. Relying on data availability, the sample covers the 
period 1980:1 - 2010:4. Next, we extend the specification to incorporate private consumption while replacing total public spending with different categories of (productive) public spending like capital expenditure on social and community services as well as economic services. Thereafter, we examine the alternate effects of government revenue shocks (using oil revenue and indirect business taxes) on capital expenditure, real output, inflation, real interest rate and private investment.

Using the recursive identification scheme, we found that the responses of real output and inflation to public spending shocks may be imprecise and depends crucially on the component of government spending used as a stabilization tool. Precisely, a positive shock to government capital spending on social and community services was found to generate a persistent positive and significant impact on real output but at a cost of inflation in the short term. However, while the response of real output was unambiguously positive the response of inflation to total expenditure and other category of public spending was persistently negative and mostly insignificant. On the other hand, a positive shock to oil revenue generates a significant positive impact on real output through its impact on public spending. In terms of innovations in indirect business taxes, real output reacts negatively though insignificant. Overall, the results indicate that apart from real interest rate, business taxes is not a crucial factor that influences private investment decisions in Nigeria. The entire analysis clearly supports the argument that for the Nigerian experience, government is still relevant in stimulating real output through expenditure expansion on productive activities.

The remainder of the paper is structured as follows. A brief literature is reviewed in section two. Next, we present the model in the third section. Section four contains the estimation results and its discussion. Section five concludes with policy options.

\section{The Literature}

\subsection{Theoretical Overview}

From a theoretical perspective, there is no single or straightforward answer regarding the sign and magnitude of the impact of discretionary fiscal policy on aggregate demand: it depends crucially on a number of key assumptions including the existence or otherwise of nominal price rigidities, the elasticity of labour supply, the responsiveness of investment to interest rate changes, the role played by forward-looking agents, etc. (de Castro and de Cos, 2008).

However, the arguments in support of activist fiscal policy laid emphasis on the fact that fiscal policy may be very effective during recessions when monetary policy can no longer be used to stimulate aggregate demand (Eggerston and Krugman, 2012). The critics of this position, on the other hand, cast doubt on the efficacy of such actions and argue that such a stabilization effect is unlikely to be effective as it can be weakened by the expectations of rational economic agents who react to government's policy decision (Barro, 2009). More so, the non-Keynesian effects of fiscal policy are further justified by the new classical school with supplyside oriented models and the Ricardian equivalence theorem. According to the Ricardian theorem, if households are forward-looking and fully aware of the government's intertemporal budget constraint, they will anticipate that a tax cut in the current period, financed by issuing government debt, will be accompanied by higher taxes imposed on them in the future. If the Permanent Income hypothesis describes the consumption behavior of households, it means that permanent income is unaffected and therefore in the absence of liquidity constraints, consumption will not change ${ }^{1}$.

Usually, following the standard IS-LM model, the impact of fiscal policy on real output is predicated on the sensitivity of private investment and money demand to variations in interest rate. The higher the sensitivity of investment to interest rate and the lesser the sensitivity of money demand to interest rate, the larger the crowing out effect of fiscal policy. In an open economy, the effectiveness of fiscal policy is theorized to depend on the exchange rate regime and assumptions regarding capital mobility. With a flexible exchange rate regime and perfect capital mobility, theory suggests that fiscal policy is inefficient as increase in government expenditure only leads to appreciation of the exchange rate with no effect on output. On the other hand, fiscal policy is said to be effective under a fixed exchange rate regime with imperfect capital mobility assumption.

Furthermore, according to the new classical school, prices and wages are assumed to be fully flexible. One major implication of this is that fully anticipated fiscal policies have no short and long-term effects on real output but would only lead to higher inflation (Lucas, 1975; Sargent and Wallace, 1975). Basically, the distinctive feature of the new classical models is that prices clears the market, such that fluctuations in output are the result of supply-side shocks and not from changes in aggregate demand.

Aside from the above, the literature has also provides other explanations concerning why fiscal policy may or may not exert the expected impact on economic activity. One of such issues is institutional factors. The argument here is that fiscal measures could be subjected to long decision lags because their design, approval and implementations may be protracted. Usually, the government has to formulate the budget bill, submits to the National Assembly who rejects or modifies and passes it. Such long lags tends to reduce the extent of the short-term fiscal multiplier (Capet, 2004). There is also an issue of outside lags which reflects the time it takes for fiscal policy to feed through to changing aggregate demand. Generally, to the extent that there is no unique

\footnotetext{
${ }^{1}$ The Ricardian equivalence thesis has been criticized in several ways. For instance, it is argued that households may be unable to smooth their consumption when faced with higher taxes in the presence of liquidity constraint. Under such condition, they would reduce their current consumption when taxes are raised. Indeed Romer (2006: 569) has outline many other reasons why the Ricardian equivalence may not hold exactly in practice as predicted.
} 
theoretical explanation ${ }^{2}$ regarding the macroeconomic effect of fiscal policy, it is important to have an empirical assessment of these effects.

\subsection{Overview of the Empirical Literature}

As opposed to traditional macroeconomics, current trends in modern macroeconomics views the economy as a dynamic, stochastic system, which can be understood by analyzing the responses to present and past random shocks. Following this perspective, vector autoregressions (VARs) are well suited as an empirical tool and a large body of literature has successfully applied them to the analysis of the effects of policy shocks (Mountford and Uhlig, 2005). However, as earlier noted, the study of fiscal policy shocks and policy interactions in VAR models is relatively limited mostly for developing countries. Some of the studies on this direction (with focus on developed countries) built largely on the Blanchard and Perotti (2002) fiscal policy framework (e.g. Perotti, 2002; Chung and Leeper, 2007; Favero and Giavazzi, 2007).

In their study for the US, Blanchard and Perotti (2002) employs a three-variable VAR that includes GDP, direct government expenditure and net revenue. They identify fiscal shocks by exploiting the decision lags in fiscal policymaking (with the assumption that discretionary government spending and revenues are predetermined with respect to the macroeconomic variables) and the information about the elasticity of fiscal variables to economic activity (which enables the identification of automatic response of fiscal policy). Their results show that expansionary fiscal shocks increase output; private consumption and investment respectively react positively and negatively to direct expenditure shock.

Raffaela, Momigliano, Neri and Perotti (2008) examines the effects of fiscal policy shocks on private GDP, inflation and long-term interest rate in Italy using a SVAR model. Utilizing data for the period 1982:1 - 2004:4 and using Blanchard and Perotti (2002) identification method, the authors found that a shock to government purchases of goods and services has a sizable and robust effect on economic activity. The effects on employment, private consumption and investment were also found to be positive. However, the response of inflation was found to be positive but small and short-lived. Applying the same methodology, Ravnik and Zilic (2011) rely on monthly to examine the macroeconomic effects of fiscal policy shocks for Croatia. Among other results, the study found that an expenditure shock decreases inflation in the short term and raises it in the medium term. Further, they show that expenditure shocks reduces industrial production while revenue shocks increases it permanently. Perhaps one clear shortcoming of this study was the use of index of industrial production to proxy real output.

\footnotetext{
${ }^{2}$ For an excellent review of theoretical literature on the efficiency of fiscal policies, see Hemming, Kell and Mahfouz (2002) and Capet (2004).
}

In a study for the Spanish economy, De Castro and de Cos (2006) find a positive relationship between expansionary government spending shock and output in the short-term but at the cost of higher inflation. However, in the medium and long-term, the authors found that expansionary spending shocks are associated with lower output. Also their results show that increase in taxes constitutes a drag on economic activity in the medium term but a temporary improvement of the public budget balance.

In another study for the US economy, Mountford and Uhlig (2002) proposed and used an identification scheme of sign restrictions on the impulse responses. They found that government spending shocks crowd out both residential and non-residential investments but leave consumption unaffected. Further, the study reveals that a cut in deficit spending stimulates the economy for the first four quarters but has low median multiplier of 0.5 , and that a positive shock to tax generates a contractionary effect on output, consumption and investment. Conclusively, the authors argued that the best fiscal policy for stimulating aggregate economic activities tends to be a deficit-financed tax cut. A similar conclusion was drawn in their subsequent study (Mountford and Uhlig, 2005). In yet another study for the US, Fu, Taylor and Yucel (2003) assess the relationship between fiscal policy and US growth under a VAR methodology. In contrast to other studies for the US, the authors found that an increase in government size (public spending) leads to slower economic growth, regardless of how the expenditure was financed. Their results differ sharply with previous evidence for the US obtained by Edelberg, Eichenbaum and Fisher (1999) under a different identification scheme. Specifically, the authors study the response of the US economy to specific episodes of military build-ups and conclude that there is a significant and positive short-run effect on output.

Biau and Girard (2005) use a five-variable VAR (government direct spending, net revenue, GDP, interest rate and the price level) to examine the effects of fiscal policy shocks in France. They found a positive reaction of private consumption while the effects on private investment was also found to be positive but only in the first year. Using a Bayesian SVAR and a recursive identification scheme, Afonso and Sousa (2009) analyze the macroeconomic effects of fiscal policy shocks for the US, UK, Germany and Italy. Their results show that government spending shocks, in general, have a small effect on output, depreciates real exchange rate, but varied impact on housing prices.

Mancellari (2011) attempts an estimation of the effect of fiscal policy on output, prices and interest rates in Albania using structural VAR. Utilizing data for the period 1998:12009:4 and following the methodology of Blanchard and Perotti (2002), the author found that a tax cut has the highest cumulative multiplier effect on output and up to 1.65 after five quarters. The study also found capital expenditure has a higher multiplier effect on output (after one quarter) than current expenditure. The response of 
interest rate following a fiscal spending shock was found to be insignificant while there was a slight increase in prices following a current expenditure shock.

In a relatively recent study, Parkyn and Vehbi (2013) examine the macroeconomic effects of fiscal policy in New Zealand using a five-variable SVAR model for the period 1983:1-2010:2. Their results indicate that government expenditure shocks has a modest effect on output in the short term, but lowers it in the medium to long-term. While they found a positive but limited impact on inflation following a fiscal expansion, the sign of the effects of tax policy changes were less clear cut. A clear insight from the above review is that there is no unique conclusion on the effect of fiscal policy on the macro-economy. The results differ from one country to another and various methodological approaches adopted.

\section{The Method}

\subsection{The SVAR Specification}

Our benchmark specification of the VAR includes quarterly data on the following five variables ${ }^{3}$ : government consumption expenditure $\left(g_{t}\right)$, real output $\left(y_{t}\right)$, inflation rate $\left(p_{t}\right)$, real interest rates $\left(i_{t}\right)$ and private investment $\left(i n_{t}\right)$. All the variables, except inflation and interest rates, are logtransformed. Nominal variables were transformed into real variables using GDP deflator. Based on data availability, our sample covers the period 1980:1 - 2010:4.

The compact form of our structural VAR model (in matrix notation) is defined by the following dynamic equation:

$$
\Gamma X_{t}=B(L) X_{t-1}+U_{t}
$$

where $X_{t} \equiv\left(g_{t}, y_{t}, p_{t}, i_{t}, i n_{t}\right)$ is the vector of endogenous variables, $\Gamma$ is the matrix of coefficients of the endogenous variables, $\mathrm{B}(\mathrm{L})$ is an autoregressive polynomial in the lag operator $\mathrm{L}$ and $U_{t} \equiv\left(u_{t}{ }^{g}, u_{t}{ }^{y}, u_{t}{ }^{p}, u_{t}{ }^{i}, u_{t}{ }^{i n}\right)$ is the vector of reduced-form innovations which are assumed to be normally distributed with a constant variance-covariance matrix, $\Sigma_{u}=E\left(u u^{\prime}\right)$. Our benchmark specification includes a constant and a linear time trend, which is however omitted from the notation for sake of convenience. The choice of the optimal lag length would be determined on the basis of the information provided by five selection criteria: the Likelihood Ratio (LR) test, Final Prediction Error (FPE), Akaike Information Criterion (AIC), Schwarz Information Criterion (SIC) and Hannan-Quinn Information Criterion (HQ).

To transform eqn. (1) into a reduced VAR model, we premultiply by $\Gamma^{-1}$ to have:

$$
X_{t}=\Gamma^{-1} B(L) X_{t-1}+\epsilon_{t}
$$

Or simply,

\footnotetext{
${ }^{3}$ Some of the data were not available at quarterly frequency and therefore an interpolation filter was used to transform the data into quarterly frequency.
}

$$
X_{t}=B^{*}(L) X_{t-1}+\epsilon_{t}
$$

Where $B^{*}=\Gamma^{-1} B$ and $\epsilon_{t}=\Gamma^{-1} U_{t}$. The variancecovariance matrix of the reduced form model can be written as $\Sigma_{\varepsilon}=\Gamma^{-1} \Sigma_{u} \Gamma^{-1^{\prime}}$. The reduced form model as shown in eqn. (3) expresses each of the endogenous variable solely as a function of predetermined variables.

\subsection{Identification of Fiscal Policy Shocks}

The main purpose of structural VAR (SVAR) estimation is to obtain non-recursive orthogonalization of the error terms for impulse response analysis ${ }^{4}$. However, as noted by de Castro and de Cos (2008), the innovations of the reducedform model as shown in eqn. (3) have limited economic significance since they are mere linear combinations of structural shocks. Thus, in respect of the present study, and following Blanchard and Perotti (2002) and Perotti (2002), the reduced-form innovations of fiscal variable (government spending) equation can be expressed as linear combinations of the structural fiscal shocks $\left(v_{t}^{g}\right)$ and of the innovations of the other reduced-form equations of the VAR as follows:

$$
\epsilon_{t}^{g}=\pi_{y}^{g} \epsilon_{t}^{y}+\pi_{i}^{g} \epsilon_{t}^{i}+\pi_{p}^{g} \epsilon_{t}^{p}+\pi_{i n}^{g} \epsilon_{t}^{i n}+v_{t}^{g}
$$

Where $v_{t}{ }^{g}$ is the structural orthogonal shock of government spending. The coefficients $\pi_{i}{ }^{j}$ denote both the automatic elasticity of fiscal variable $\mathrm{j}$ to the macroeconomic variable $\mathrm{i}$ (i.e. $\mathrm{y}, \mathrm{i}, \mathrm{p}$ and in) and the discretionary change in variable $\mathrm{j}$ initiated by the policymaker in response to an innovation in these macro-variables. Fundamentally in this paper, our interest is to analyze the impacts of the structural (discretionary) shock $\left(v_{t}{ }^{g}\right)$ on the rest of the variables in the system

To identify the orthogonal (structural) components of the error terms requires the imposition of some restrictions on the impulse response functions. There are at least four different approaches in the literature for achieving the required identification. These include: (1) the event-study approach that identifies fiscal policy shocks through the use of dummy variables to capture specific episodes in the system (as used by Ramey and Shapiro, 1998 and Edelberg, et al., 1998); (2) the sign-restrictions approach (as used in Mountford and Uhlig, 2005 and Bracke and Fideora, 2008); (3) the exploitation of decision lags in policy formulation and utilization of information on the elasticity of fiscal variables to economic activity (as used in Blanchard and Perotti, 2002 and Perotti, 2002); and finally (4) the recursive ordering (Choleski decomposition) approach (as used in Fatas and Mihov, 2001 and Favero, 2002). This latter approach is the one we follow in this paper.

Usually the identification scheme using the recursive approach requires that the contemporaneous exogenous variables be ordered first. Thus in our case, we assume that government spending is exogenous and predetermined and therefore does not react contemporaneously to shocks to

\footnotetext{
${ }^{4}$ The identifying restriction that distinguishes SVAR methodology from the traditional dynamic simultaneous equation approach is the assumption in SVAR models that the structural innovations are orthogonal, that is, they are uncorrelated.
} 
other variables in the system. This assumption seems plausible given that government spending is usually predetermined in national budget and very unlikely to response to business cycle within a quarter. This restriction implies that government spending shock is affected only by shocks to itself. Real output is ordered next as we assume it to be affected by its own shocks and contemporaneously by government spending shock in line with the traditional Keynesian multiplier framework. This amount to imposing restrictions on the shocks to inflation, private investment and interest rate, that is, they are set to zero. Next, we assume that inflation does not react contemporaneously to private investment and interest rate shocks, but is affected by government spending and real output shocks as well as shocks to itself. A decline in growth rate of real output as well as higher government spending could lead to higher inflation. To this end, we further impose the restriction that the impact of shocks to private investment and interest rate on inflation is zero. The fourth structural restriction implies that real interest rate is affected by shocks to itself, government expenditure, real output, and inflation and not by shocks to private investment. Finally, we assume that private investment will respond to shocks to the rest of the variables in the system and thus, all the coefficients in the investment equation are freely estimated without any restriction. These structural restrictions implies that the relation between the reduced-form disturbances $\epsilon_{t}$ and the structural disturbances $v_{t}$ takes the following text form:

$$
\begin{gathered}
@ \epsilon_{t}^{g}=c(1) * @ v_{t}^{g} \\
@ \epsilon_{t}^{y}=c(2) * @ \epsilon_{t}^{g}+c(3) * @ v_{t}{ }^{y} \\
@ \epsilon_{t}^{p}=c(4) * @ \epsilon_{t}^{g}+c(5) * @ \epsilon_{t}^{y}+c(6) * @ v_{t}^{p} \\
@ \epsilon_{t}^{i}=c(7) * @ \epsilon_{t}^{g}+c(8) * @ \epsilon_{t}^{y}+c(9) * @ \epsilon_{t}^{p} \\
+c(10) * @ v_{t}^{i} \\
@ \epsilon_{t}^{i n}=c(11) * @ \epsilon_{t}^{g}+c(12) * @ \epsilon_{t}{ }^{y}+c(13) * @ \epsilon_{t}^{p} \\
+c(14) * @ \epsilon_{t}^{i}+c(15) * @ v_{t}^{i n}
\end{gathered}
$$

To provide some sensitivity check on our benchmark model, we further extend the specification to incorporate private consumption while replacing total public spending with different categories of (productive) public spending like capital expenditure on social and community services as well as economic services. Thereafter, we examine the alternate effects of government revenue shocks (using oil revenue and indirect business taxes) on capital expenditure, real output, inflation, real interest rate and private investment. In examining the alternate effect of taxes and revenue shocks, we maintained the ordering while replacing government spending with these fiscal variables ${ }^{5}$.

Before estimating the model, we first diagnose the integration properties of the times series data to guide us in the manner with which to incorporate the respective variables

\footnotetext{
${ }^{5}$ Indeed, alternative Cholesky orderings were tried in the course of the estimation, but there was no substantial differences in the results.
}

in the SVAR model. We do this using the traditional ADF and KPSS tests (Dickey and Fuller, 1981 and Kwiakowski, et al, 1992). Variables that are integrated of the first order, I(1), are incorporated in the SVAR model at their first difference and series that are stationary, $\mathrm{I}(0)$, are incorporated at their original level. All the data were extracted from $\mathrm{CBN}$ Statistical Bulletin (various years).

\section{Results and Analysis}

\begin{tabular}{|c|c|c|c|c|c|}
\hline \multirow[b]{2}{*}{ Variable } & \multicolumn{2}{|l|}{ ADF } & \multicolumn{2}{|l|}{ KPSS } & \multirow[b]{2}{*}{$\begin{array}{l}\text { Concl } \\
\text { usion }\end{array}$} \\
\hline & Level & $\begin{array}{l}\mathbf{1}^{\text {st }} \\
\text { Differe } \\
\text { nce }\end{array}$ & Level & $\begin{array}{l}1^{\text {st }} \\
\text { Differen } \\
\text { ce }\end{array}$ & \\
\hline Real output & $4.02(6)$ & $\begin{array}{l}- \\
7.65(5)^{*} \\
* *\end{array}$ & $1.28(9)$ & $\begin{array}{l}0.26(11) \\
* * *\end{array}$ & $\mathrm{I}(1)$ \\
\hline $\begin{array}{l}\text { Private } \\
\text { Consumption }\end{array}$ & $-2.16(9)$ & $-1.16(8)$ & $\begin{array}{l}0.64(9) \\
* *\end{array}$ & $\begin{array}{l}0.23(6)^{*} \\
* *\end{array}$ & $\mathrm{I}(1)$ \\
\hline $\begin{array}{l}\text { Indirect } \\
\text { Business Tax }\end{array}$ & $-2.62(9)^{*}$ & $-2.53(8)$ & $0.78(9)$ & $\begin{array}{l}0.27(7)^{*} \\
* *\end{array}$ & $\mathrm{I}(1)$ \\
\hline $\begin{array}{l}\text { Capital Gov. } \\
\text { spending }\end{array}$ & $-1.57(9)$ & $-2.47(8)$ & $1.05(9)$ & $\begin{array}{l}0.08(4)^{*} \\
* *\end{array}$ & $\mathrm{I}(1)$ \\
\hline Inflation & $-2.61(9)^{*}$ & $\begin{array}{l}- \\
3.61(8)^{*} \\
* *\end{array}$ & $\begin{array}{l}0.22(8) \\
* * *\end{array}$ & $\begin{array}{l}0.06(5)^{*} \\
* *\end{array}$ & $\mathrm{I}(0)$ \\
\hline Interest Rate & $-2.25(9)$ & - & $\begin{array}{l}0.45(9) \\
* *\end{array}$ & $\begin{array}{l}0.17(15) \\
* * *\end{array}$ & $\mathrm{I}(1)$ \\
\hline Oil Revenue & $0.27(9)$ & $-2.43(8)$ & $1.04(9)$ & $\begin{array}{l}0.27(6)^{*} \\
* *\end{array}$ & $\mathrm{I}(1)$ \\
\hline $\begin{array}{l}\text { Private } \\
\text { Investment }\end{array}$ & $\begin{array}{l}- \\
3.87(5)^{* *} \\
*\end{array}$ & $\begin{array}{l}- \\
3.07(4)^{*}\end{array}$ & $\begin{array}{l}0.29(9) \\
* * *\end{array}$ & $\begin{array}{l}0.44(6)^{*} \\
*\end{array}$ & $\mathrm{I}(0)$ \\
\hline $\begin{array}{l}\text { Capital } \\
\text { Spending on } \\
\text { ES }\end{array}$ & $-0.89(9)$ & $\begin{array}{l}- \\
2.11(12)\end{array}$ & $\begin{array}{l}0.20(8) \\
*\end{array}$ & $\begin{array}{l}0.04(6)^{*} \\
* *\end{array}$ & $\mathrm{I}(1)$ \\
\hline $\begin{array}{l}\text { Capital } \\
\text { Spending on } \\
\text { SCS }\end{array}$ & $4.70(5)$ & $5.57(5)$ & $\begin{array}{l}0.67(8) \\
*\end{array}$ & $\begin{array}{l}0.54(8)^{*} \\
*\end{array}$ & $\mathrm{I}(1)$ \\
\hline
\end{tabular}

Table 1 displays the results for the unit root test. The results using the ADF statistic indicate that some of the variables (e.g. oil revenue, interest rate, capital expenditure and private consumption) were $\mathrm{I}(2)$ as stationarity were not found even at 1 st difference.

Table 1. Unit Root Test Results.

Notes: $* * * * *$ and $*$ indicates significance at the $1 \%, 5 \%$ and $10 \%$ levels respectively. The values in bracket for the ADF test indicate the optimal lag length selected by the SIC within the maximum lag of 13 , while those for the KPSS test indicate the bandwidth selection using the Newey-West's Barlett Kernel method. Test assumptions for both the ADF and KPSS include constant intercept. ES = Economic Services, SCS = Social and Community Services

However, using the KPSS statistic, all the variables (except inflation and private investment) were confirmed to be stationary at first difference. Only inflation and private investment were shown to be stationary at levels. Although the results of the SVAR estimates does not truly depends on the stationarity properties of the variables, we rely on the results based on the KPSS test and incorporate them in their respective levels in our estimation. 


\subsection{The Effect of Public Spending Shock}

Figure 1 presents our benchmark results on the impulse responses of the endogenous variables to a positive government expenditure shock. The two dotted lines represent the $5 \%$ asymptotic error bands, while the solid lines

Government expenditure

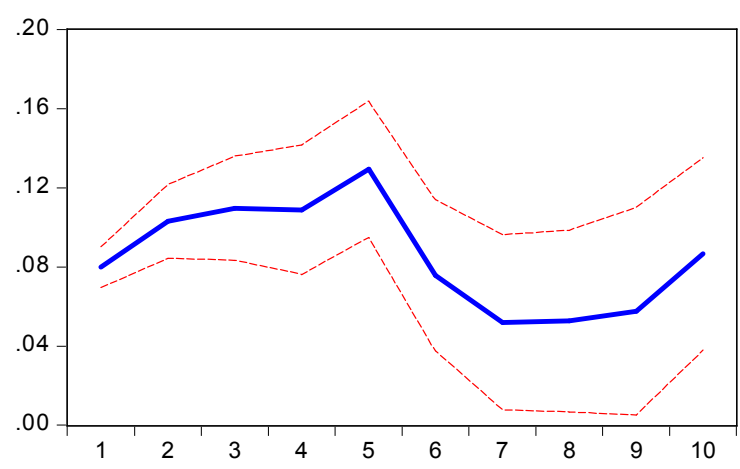

Real GDP

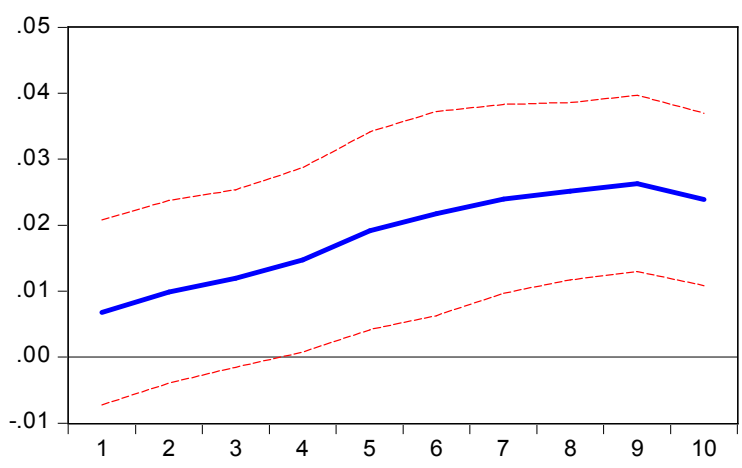

Private Investment

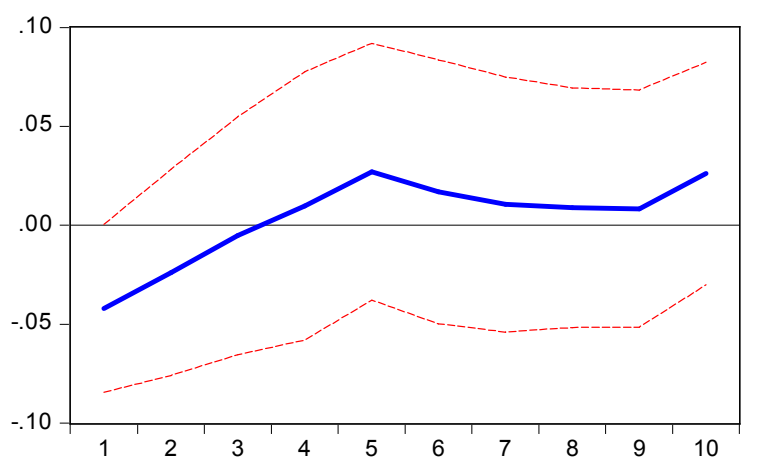

represent the impulse function. As expected, government spending shock is highly persistent and significant to its own shock or innovations. The high persistence of government expenditure shocks is a typical findings of most empirical studies on fiscal policy shocks (see Blanchard and Perotti, 2002; de Castro and de Cos, 2008; Perotti, 2002).

Inflation

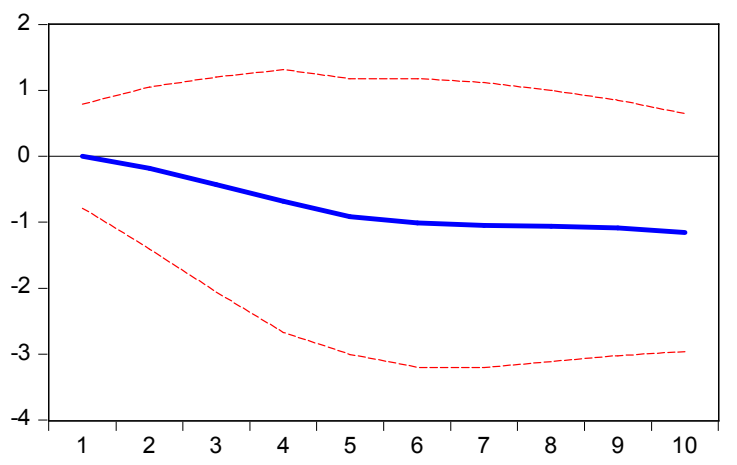

Interest Rate

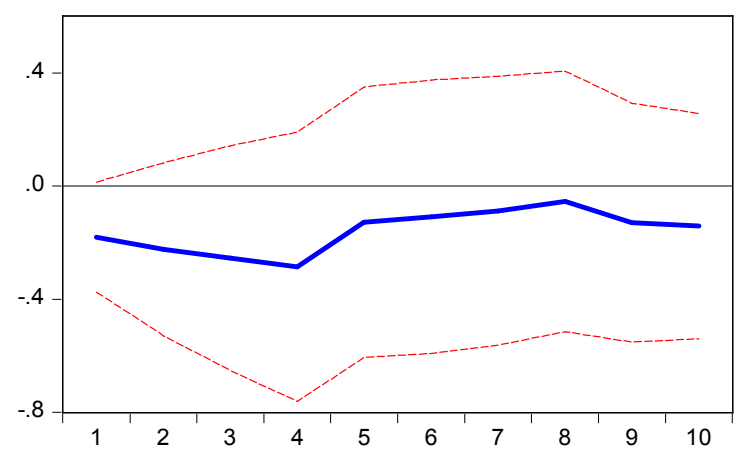

Figure 1. Response to an increase in government spending (Cholesky One S.D. Innovations \pm 2 S.E.).

Interestingly, government spending shock has a positive impact on real output. This effect is persistent and significant after the first 4 quarters. Clearly, this is a useful results as it confirms that government spending is a veritable instrument that can be used to stabilize the Nigerian economy. Similar conclusions on the positive effect of government spending shock on real output has been reported in de Castro and de Cos (2008) for Spain and Parkyn and Vehbi (2013) for New Zealand.
However, the responses of other endogenous variables were not significant. An important aspect of the result is that total government expenditure appears not to be responsible for inflationary pressure in Nigeria. The response of inflation to a positive shock to government spending was not only negative but insignificant. Interestingly also, there is no conclusive evidence on the effects of government spending shocks on inflation in the empirical VAR literature. For instance, while de Castro and de Cos (2008) reported a 
significantly positive response of prices for Spain, Fatas and Mihov (2001) as well as Mounford and Uhlig (2005) show negative effects on prices after a positive shock to government spending in the US. Yet in another study, Marcellino (2002) finds minor and insignificant response of inflation to a positive government spending shock in Germany, Italy and Spain but a significant positive effect in France in the short term.

\subsection{The Effect of Different Categories of Public Spending}

To account for the different categories of public spending and therefore provide a sensitivity check for our baseline results, we replace total government spending with capital expenditure on social and community services and thereafter with capital spending on economic services. Components of

Spending Social and Community Services

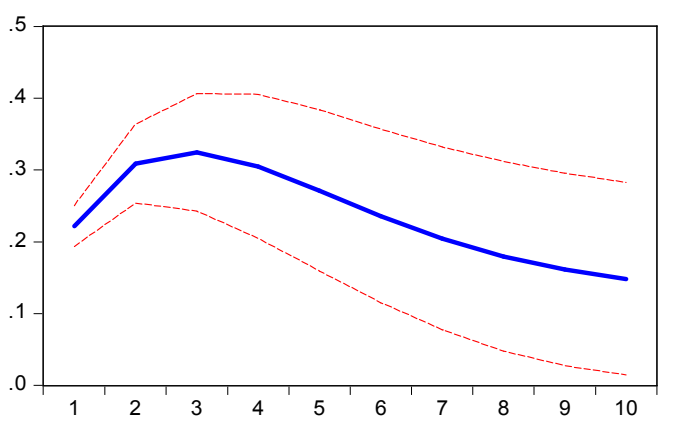

Inflation

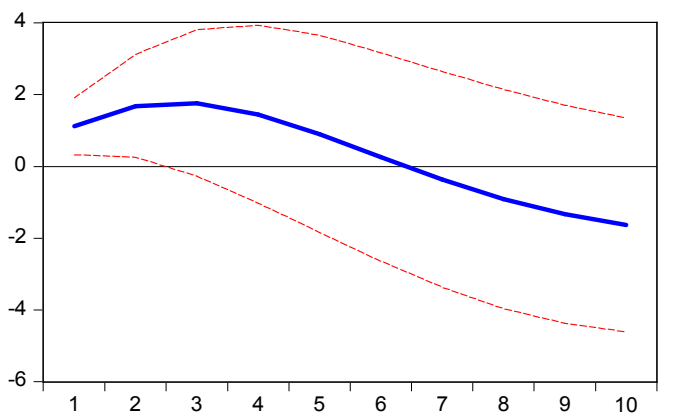

Private Investment

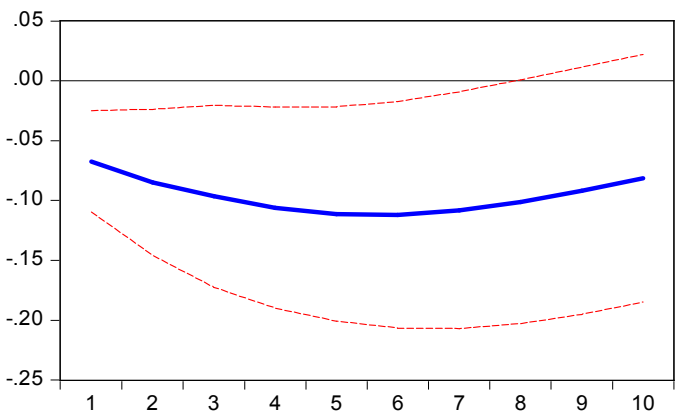

social and community services expenditure include education and health while that of economic services include agriculture, construction as well as transport and communication. Included however in addition to the benchmark specification is private consumption spending. The Cholesky ordering of the variables was maintained with private consumption ordered last. Ideally, capital expenditure on health and education are expected to have reasonable impact on real output and indirectly brings positive spillover effect on private consumption (e.g. through its impact on private wages and improved productivity). Figure 2 shows the corresponding impulse responses of the endogenous variables to a positive shock in government capital spending on social and community services.

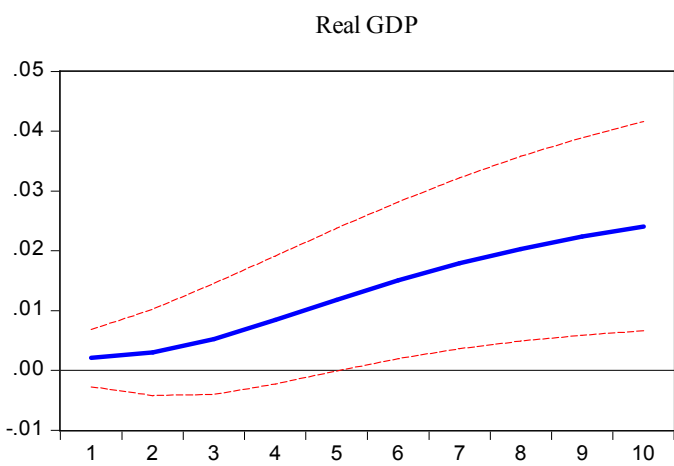

Interest Rate

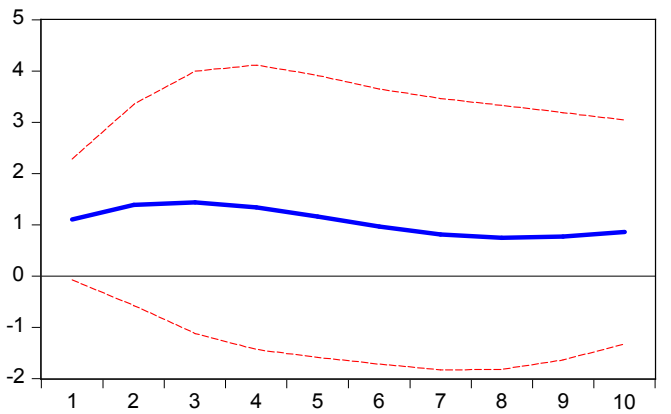

Private Consumption

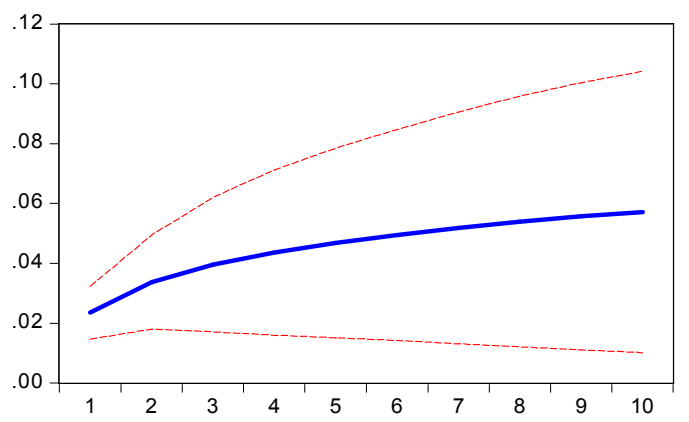

Figure 2. Response to an increase in Capital Spending on Social and Community Services (Cholesky One S.D. Innovations \pm 2 S.E.).

The results is very revealing and interesting. Similar to the effect of total government spending, positive shock to social and community spending in Nigeria has a persistent positive impact on real output. In the short term, the estimated impact is insignificant but becomes statistically significant after the 5 th quarter. However, unlike the transmission effect of total government spending, the stimulation of real output comes with an initial cost of higher inflation in the first quarter. 
Over time, inflation declines, becomes negative and insignificant. This suggest that a shock to this category of government spending (social and community services) is growth enhancing in the medium term but at a cost of higher inflation in the short term.

In the same vain, the response of interest rate to a shock in public spending on social and community services remains relatively positive but insignificant. This in turn, leads to a significant negative response of private investment, following the shock. Overall, the results suggest that the main driving factor for the increase in real output is private consumption rather than investment. As shown, the response of private consumption to a positive shock in this category of

Spending on Economic Services

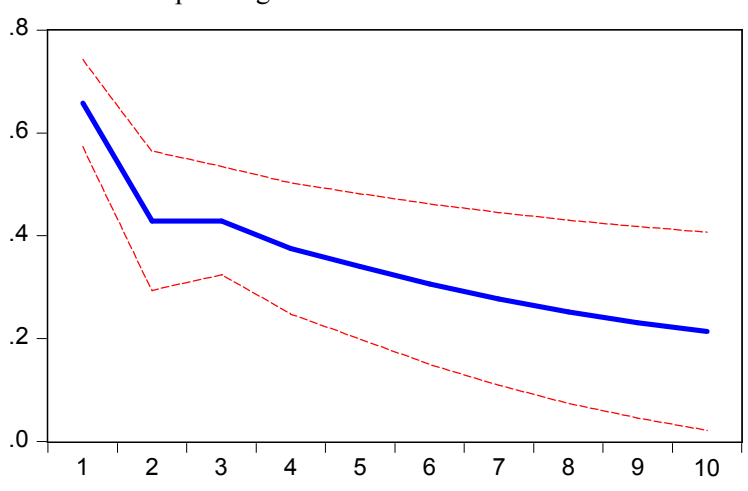

Inflation

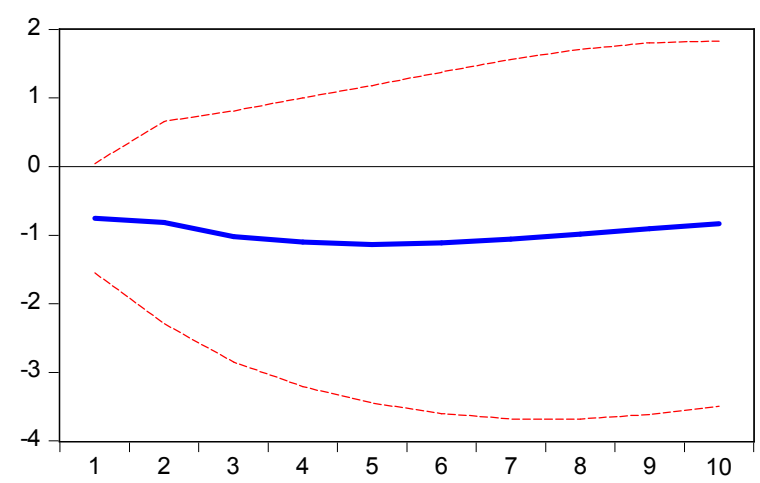

Private Investment

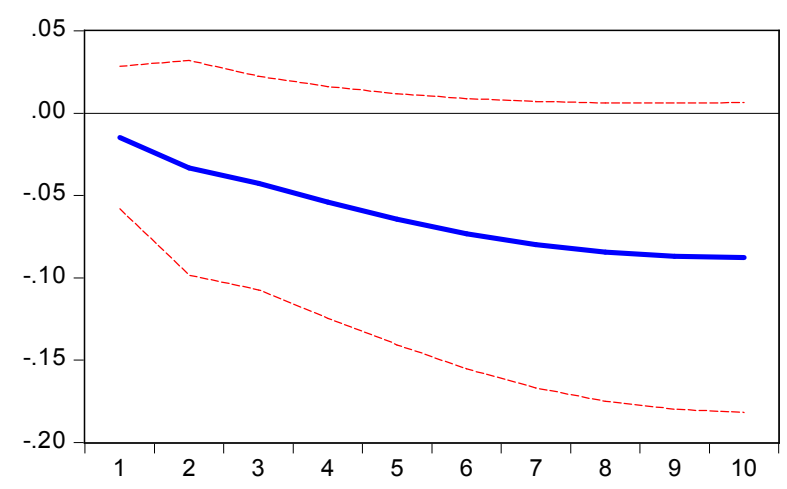

public spending remain highly significant and positive without any tendency of fading away.

The results of the impulse responses to another category of government spending - public capital spending in economic services - is displayed in Figure 3. Apart from inflation, the response of other endogenous variables are somewhat similar to previous evidence we have on public spending on social and community services. However, here, most of the responses are largely insignificant. Taken together, the evidence points to the positive multiplier effect of government spending shock on real output, but whether prices will rise or fall depends crucially on the specific component of government spending.

Real GDP

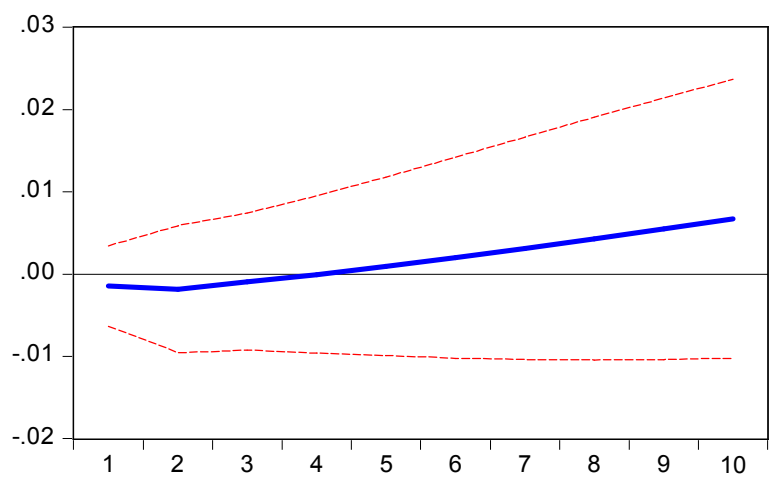

Interest Rate

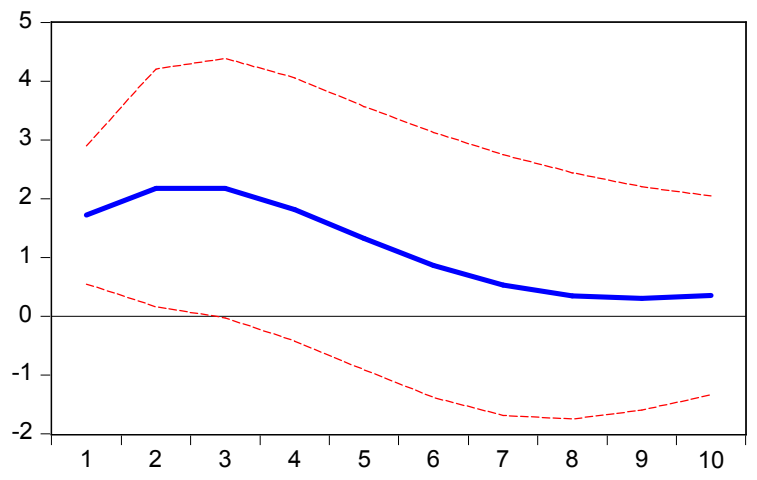

Private Consumption

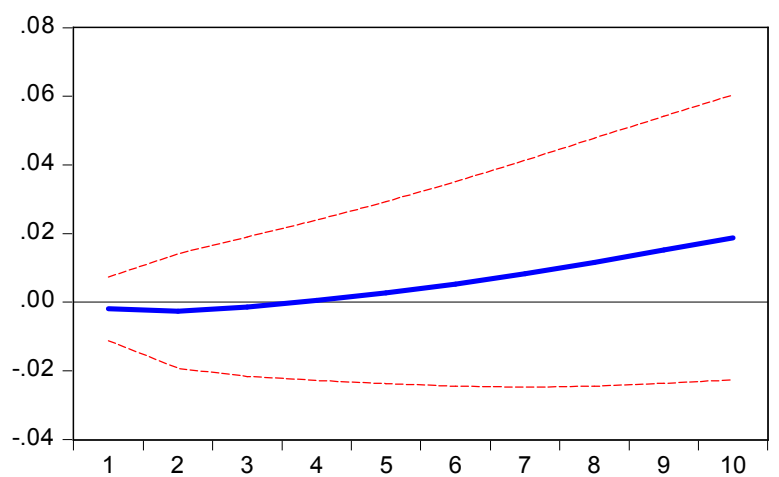

Figure 3. Response to an incraese in Government Capital Spending on Economics Services (Cholesky One S.D. Innovations \pm 2 S.E.). 


\subsection{The Effect of Shocks to Oil Revenue and Taxes}

Oil Revenue

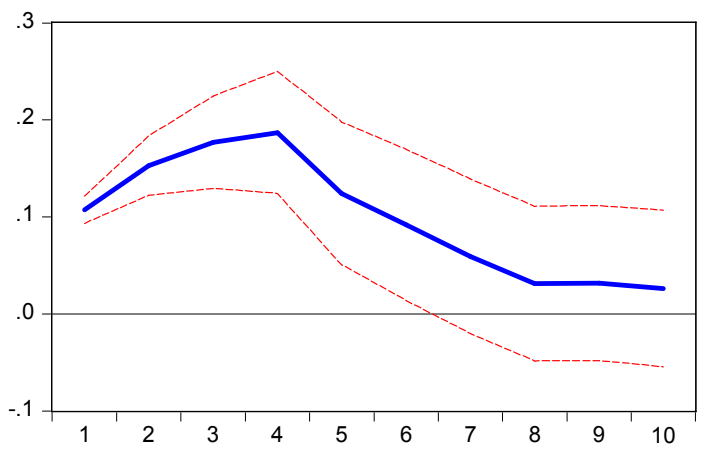

Real GDP

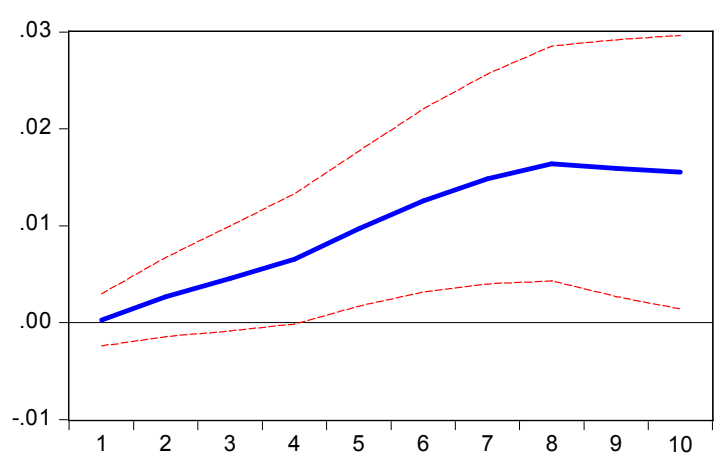

Interest Rate

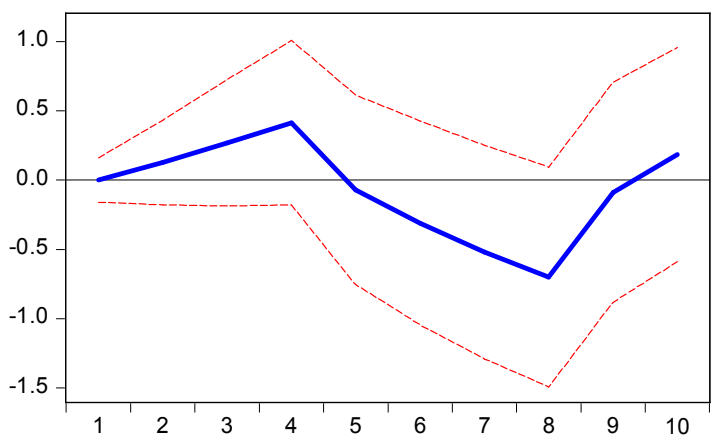

Government Capital Expenditure

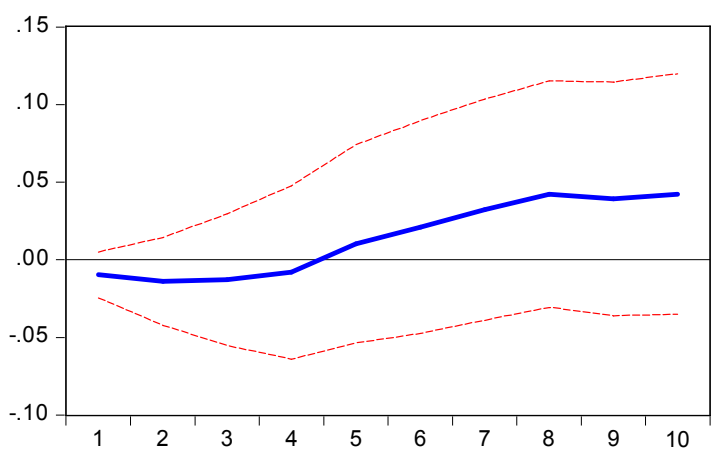

Inflation

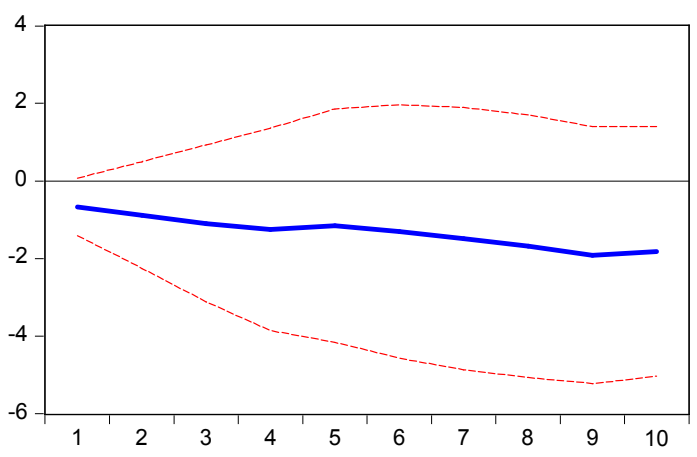

Private Investment

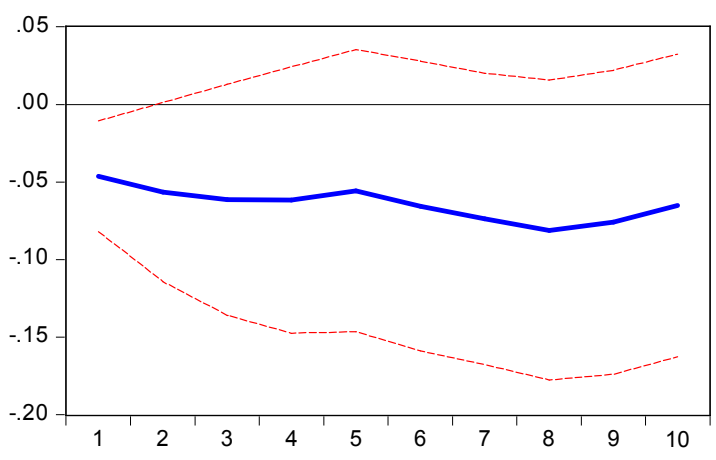

Figure 4. Response to an increase in Oil Revenue (Cholesky One S.D. Innovations \pm 2 S.E.).

Figure 4 shows the responses of endogenous variables to a positive shock to oil revenue in Nigeria. The impact of oil revenue shock on government capital expenditure remains positive after the 4 th quarter but surprisingly insignificant ${ }^{6}$. The insignificant response of government capital spending may be attributed to the fact that government spending is already predetermined in the budget and also to the creation of the sovereign wealth fund by the Federal Government. Another reason could be the administrative lag and contractual bottleneck sometimes involved in executing most capital projects in Nigeria. However, the behavior of interest

\footnotetext{
${ }^{6}$ When government capital expenditure was replaced with total government expenditure, the response of the latter was persistently positive but insignificant.
}

rate is less intuitive. It increases positively within the first 4 quarter and turns negative thereafter before reverting back to equilibrium after the 8th quarter. Although the initial response of private investment was negative and significant within the first 2 quarters, its overall response for the rest of the quarters remains negative and insignificant.

Overall, and in conformity with previous evidence, a positive shock to oil revenue significantly raises real output through the multiplier effect of government spending. Our finding is compatible with other empirical evidence (e.g. de Castro and de Cos, 2008). On the other hand, the response of inflation yield a negative and insignificant effect. This evidence indicates that inflationary pressures in Nigeria may not have been moderated by oil price shock.

Figure 5 displays the effect of a shock to taxes on the 
endogenous variables in the VAR model. The results are very informative. In line with theory, the response of real output to a one standard deviation innovations in business taxes is negative, though insignificant. The decline in output is very persistent throughout the quarters and shows no tendency of reverting back to its baseline value. This result is in line with those reported by Blanchard and Perotti (2002) and Parkyn and Vehbi (2013) but differs from the findings reported by Giordano, et al (2007) for Italy, De Castro and de Cos (2008) for Spain and Tang, et al (2011) for some East Asian countries.

In addition, the result in Figure 5 reveals that the financing of government capital project is not positively responsive to its tax revenues. Indeed, government capital spending remains negative and insignificant after the positive shock to

Indirect Business Taxes

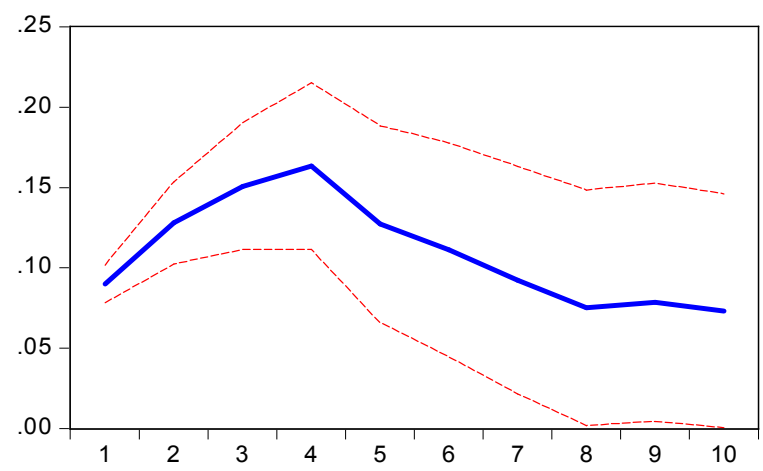

Real GDP

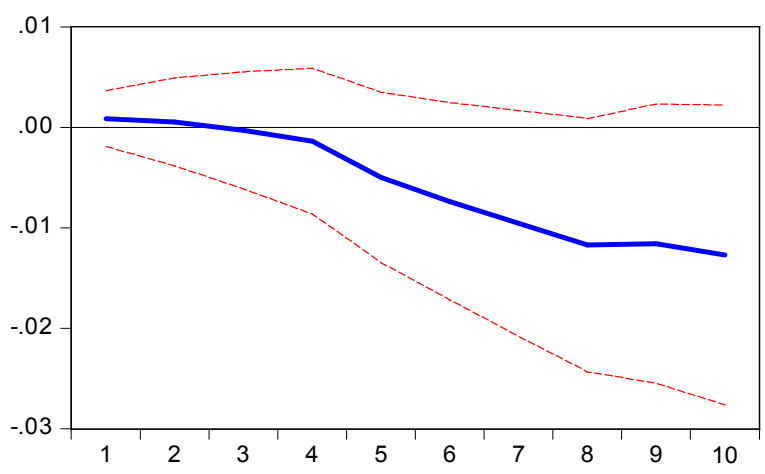

Interest Rate

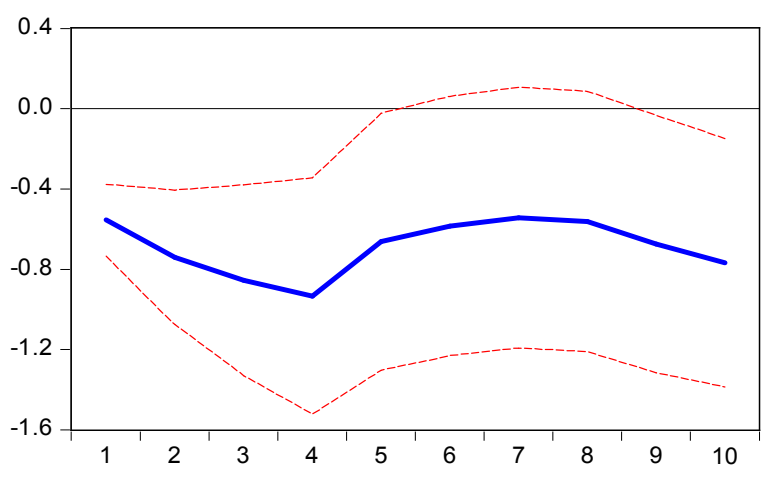

business taxes with no tendency of reverting to its equilibrium value. Surprisingly, the response of private investment was significantly positive for the first 5 quarters and remains positive but insignificant for the rest of the period. From the results, it suggests that investment decisions in Nigeria may not depend on the indirect taxes paid to government, but rather on other crucial variables like market demand, profit expectations and the cost of capital (interest rate). Indeed as the result reveals, the significant jump in private investment is accompanied by a significant reduction in the cost of borrowed funds (interest rate). On the other hand, inflation falls in response to an increase in indirect taxes, which seems to be explained by the subdued economic activity occasioned by the steady reduction in real output.

Government Capital Expenditure

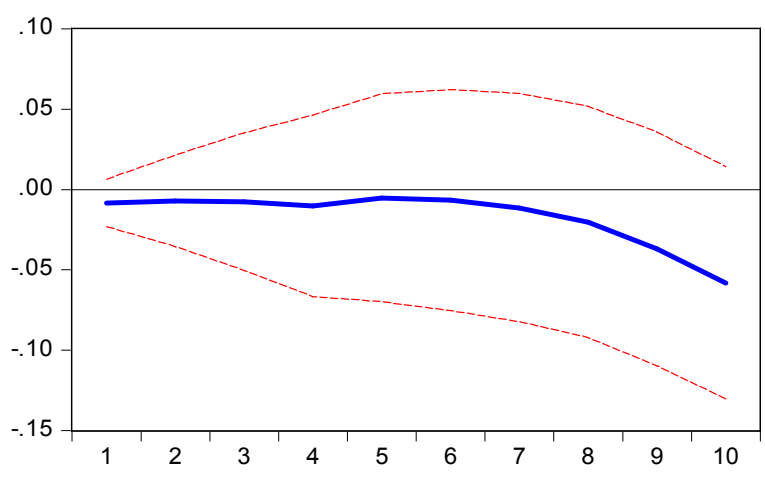

Inflation

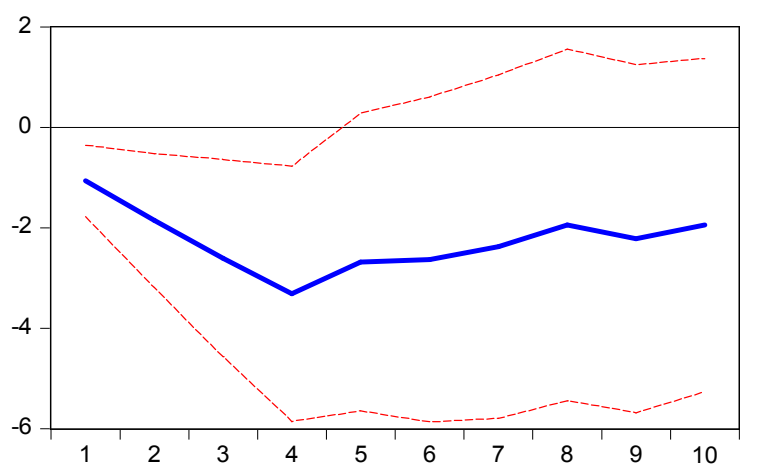

Investment

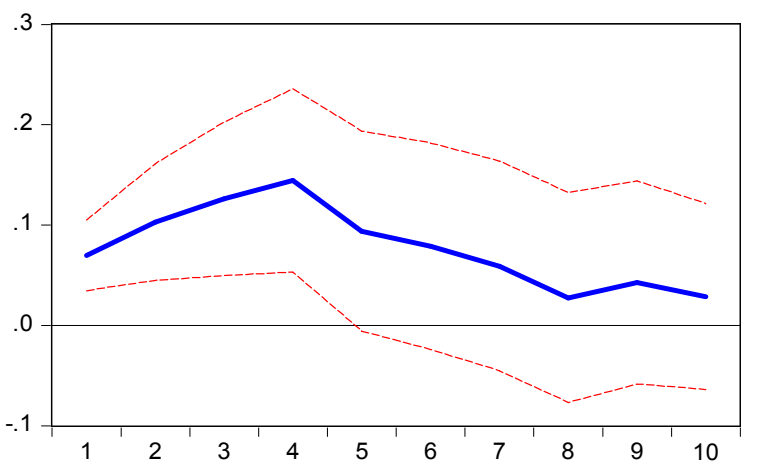

Figure 5. Response to an increase in Indirect Business Taxes (Cholesky One S.D. Innovations \pm 2 S.E.). 


\section{Conclusion}

This paper investigates the macroeconomic effects of fiscal policy shocks in Nigeria using a SVAR methodology. The main results from this study can be summarized as follows. The responses of real output and inflation may be asymmetrical depending on the component of government spending used as a fiscal stimulus to stabilized the economy. Fundamentally, a positive shock to government capital spending on social and community services has a persistent positive and significant impact on private consumption and real output but at the cost of higher inflation in the short term. However, while the impact of real output is unambiguously positive, the response of inflation to total expenditure and other category of public spending remains consistently negative and most often insignificant. A positive shock to oil revenue has a significant positive impact on real output through its impact on public spending. In line with theory, the response of real output to innovations in business taxes is persistently negative, though insignificant. Private investment decisions in Nigeria does not depend on the indirect taxes paid to government, but on the cost of capital (interest rate) and perhaps on other crucial variables like market demand and profit expectations.

At least three policy insights can be gleaned from this study. First, public spending expansion, especially on productive categories like social and community services has a sizeable and robust effect on private consumption and economic growth in Nigeria. This clearly indicates that the public sector is still very relevant in stimulating economic activities in $\mathrm{Nigeria}^{7}$. Second, the use of taxes to finance public spending in Nigeria is highly distortionary and may lead to a fall in real economic activities. Although Nigeria does not depend on taxes as it major source of revenue but on crude oil sales, a search for a less distortionary revenue base can be found in diversifying the nation's economic base from crude oil. Lastly, stimulating private investment in Nigeria may as well require a wellcoordinated monetary policy framework that moderates the rate of interest on borrowed funds.

Before ending, some caveats regarding our results are in order. Firstly, it should be taken into account that our estimates does not, to some extent, disentangle the movement in fiscal variables arising from discretionary fiscal policy shocks from those caused by automatic response of fiscal variables to other shocks like business cycle or monetary policy shocks. Interestingly, Mountford, and Uhlig (2005) have developed a method for dealing with such problems which can be taken up in further research. More so, our model did not capture expectations to take account for anticipated fiscal policy shocks. There are good reasons to believe that the reaction of the real economy to fiscal shocks may generate different outcomes in the presence of rational

\footnotetext{
${ }^{7}$ However, from a stabilization point of view, the effectiveness of discretionary fiscal policy may be limited by long decision lags, irreversibility and fiscal bias.
}

expectations by economic agents. Incorporating these issues may be important and we hope to explore this further in subsequent study. Lastly, the VAR approach usually requires the existence of reliable and non-interpolated quarterly data over a sufficient long period of time. To the extent that some of our data were not available on quarterly frequency and therefore were interpolated, our results should be interpreted with some level of caution.

\section{References}

[1] Afonso, A. and R. M. Sousa, 2009. The Macroeconomic Effects of Fiscal Policy. Working Paper Series, No. 991. European Central Bank.

[2] Barro, R.J., 2009. Government Spending is no Free Lunch. Wall Street Journal, 22.

[3] Biau, O. and E. Girard, 2005. Politique Budgetaire et Dynamique Economique en France: 1'approach VAR Structurel. Economie et Prevision, 169-171: 1-24.

[4] Blanchard, O. and R. Perotti, 2002. An Empirical Characterization of the Dynamic Effects of Changes in Government Spending and Taxes on Output. Quarterly Journal of Economics. 117 (4): 1329-1368

[5] Bracke, T. and M. Fideora, 2008. Global Liquidity Glut or Global Savings Glut? A Structural VAR Approach. European Central Bank Working Paper Series. No. 911, June.

[6] Capet, S., 2004. The Efficiency of Fiscal Policies: A Survey of the Literature. CEPII Working Paper. No. 2004-11.

[7] Chung, H. and E. M. Leeper, 2007. What has Financed Government Debt? NBER Working Paper, 13425, Cambridge, MA.

[8] De Castro, F. and P. H. De Cos., 2008. The Economic Effects of Fiscal Policy: The Case of Spain. Journal of Macroeconomics, 30: 1005-1028.

[9] Dickey, D. A. and W. A. Fuller, 1981. Likelihood Ratio Statistics for Autoregressive Time Series with Unit Root. Econometrica. 49(4): 1057-1072

[10] Edelberg, W., M. Eichenbaum and J. D. M. Fisher, 1998. Understanding the Effects of a Shock to Government Purchases. NBER Working Paper. No. 6737

[11] Edelberg, W., M. Eichenbaum and J. Fisher, 1999. Understanding the Effects of a Shock to Government Purchases. Review of Economics Dynamics, 2: 166-206.

[12] Eggertsson, G.B. and P. Krugman, 2012. Debt, Deleveraging, and the Liquidity Trap: A Fisher Minsky-Koo Approach. The Quarterly Journal of Economics, 127(3):1469-1513.

[13] Fatas, A. and I. Mihov, 2001. The Effects of Fiscal Policy on Consumption and Employment: Theory and Evidence. CEPR Discussion Papers. No. 2760, April.

[14] Favero, C., 2002. How do European Monetary and Fiscal Authorities behave? CEPR Discussion Paper Series. No. 3426

[15] Favero, C. A. and F. Giavazzi, 2007. Debt and Effects of Fiscal Policy. NBER Working Paper 12822, Cambridge, MA. 
[16] Fu, D., L. Taylor and M. Yucel, 2003. Fiscal Policy and Growth. Working Paper 0301, Federal Reserve Bank of Dallas.

[17] Hemming, R., M. Kell and S. Mahfouz, 2002. The Effectiveness of Fiscal Policy in Stimulating Economic Activity - A Review of the Literature. IMF Working Paper, $\mathrm{WP} / 02 / 208$

[18] Kwiatkowski, D., P. C. B. Phillips, P. Schmidt and Y. Shin, 1992. Testing the Null-Hypothesis of Stationary against the Alternative of a Unit Root. Journal of Econometrics, 54, 159178 .

[19] Lucas, R., 1975. An Equilibrium Model of the Business Cycle. Journal of Political Economy. 83: 1113-1144.

[20] Mancellari, A., 2011. Macroeconomic Effects of Fiscal Policy in Albania: A SVAR Approach. Working Paper 05(28), Bank of Albania.

[21] Marcellino, M., 2002. Some Stylized Facts on Non-systematic Fiscal Policy in the Euro area. CEPR Working Paper Series, No. 3635 .

[22] Mountford, A. and H. Uhlig, 2002. What are the Effects of Fiscal Policy Shocks? SFB 373 Discussion Paper 2002-31.
[23] Mountford, A. and H. Uhlig, 2005. What are the Effects of Fiscal Policy Shocks? SFB 649 Discussion Paper 2005-039

[24] Parkyn, O. and T. Vehbi, 2013. The Effects of Fiscal Policy in New Zealand: Evidence from a VAR Model with Debt Constraints, New Zealand Treasury Working Paper, No. 13/02, January.

[25] Perotti, R., 2002. Estimating the Effects of Fiscal Policy in OECD Countries. ECB Working Paper, No. 168.

[26] Raffaela, G., S. Momigliano, S. Neri and R. Perotti, 2008. The Effects of Fiscal Policy in Italy: Evidence from a VAR Model, Bank of Italy Working Paper, No. 656.

[27] Ramey, V. and M. Shapiro, 1998. Costly Capital Reallocation and the Effects of Government Spending, NBER Working Paper, No. 6283

[28] Ravnik, R. and I. Zilic, 2011. The Use of SVAR Analysis in Determining the Effects of Fiscal Shocks in Croatia. Financial Theory and Practice, 35 (1): 25-58.

[29] Romer, D., 2006. Advanced Macroeconomics. Irwin: McGraw-Hill

[30] Sargent, T. and N. Wallace, 1975. Rational Expectations, the Optimal Monetary Instrument, and the Optimal Money Supply Rule. Journal of Political Economy, 83: 241-254. 